\title{
PROPOSAL FOR BUILD A TEST STAND TO THE STUDY WATER RAM BASED ON THE RECOMMENDATIONS CONSTRUCTION
}

\begin{abstract}
The main aim of this article was developed of a test stand to a study physics phenomena accruing at work in a ram water based on the construction recommendations. The experience gained by a number of attempts allowed to the developed construction recommendations that allowed to adjust the test stand to perform various studies of physics phenomena occurring at the work of water ram and easy adaptions to the new requirements. The article includes: the review of the test stands on which performed the study in the history and in the present times, description of the construction recommendations of the universal test stand and the proposal of the test stand developed based on the construction recommendations. Motivation to take up this issue follows from the interest of devices that work in an unconventional way, devices used a renewable energy that can be used in household e.g. to improve their energy balance, delivery water to houses, drinking water for animals, fields irrigation, etc. Analysis of the literature of the water ram, test stands and their performance shown that it is small and typically old development in popular science form. In times of intensive search new sources of renewable energy reactivation of this type equipment may be highly probable.
\end{abstract}

Keywords: ram water, test stand, performance, water hammer

\section{Introduction}

Analyzing the literature information about place of locations of water ram and test stands cannot find information on manual construction of the measuring test stand based on the construction recommendations.

The main aim of the work is proposal for build the test stand used to the perform various studies of physics phenomena occurring in work of ram water based on the recommendations construction.

The motivation of the work are machinery and devices that their actions is based on an unconventional way by using renewable energy. Devices that can be

\footnotetext{
${ }^{1}$ Dariusz Grygo, Department of Mechanical and Machine Design, University of Warmia and Mazury in Olsztyn, Oczapowskiego 11, 10-719 Olsztyn, e-mail: dariusz.grygo@gmail.com
} 
used in the household e.g. to improve their energy balance, free delivery water, gardens irrigation, water processing of technological.

The paper describes an overview of the historical and present day test stands on which made the research, developed the construction recommendation to the build universal test stand, describes examples of the test stand in conclusion interpreted the test stand in relation to the aim if this publication.

This article is a continuation of the work of previous publications. In "Ram Water - the forgotten device" [6] collected basic information about ram water presented an analysis of the current possibilities of their use, and the main motivations to start testing. In "Stages work of water ram" [8] described in detail a single cycle of water ram and proposed the author's division into three phases, referring to the major changes taking place in the device physical phenomena. In „Proposals for the use of water rams " [7], proposed to groups of potential customers that can be used the water ram. Several new articles were sent to publishers. The present article is a continuation of a series of publications and presents proposal of the test stand based on the construction recommendations.

The water ram is a kind of water pump to lifting water to higher levels $\left(h_{c}\right)$ then a level height of the supply water source $\left(h_{s}\right)$ (Fig. 1). The water ram action is based on the use of the kinetic energy of water flowing through the ram. The supply water sources can be any flow e.g.: river, stream, lake, etc., important is only that the flow must provide adequate water flow $\left(\dot{V}_{s}\right)$, that will create an appropriate a water hammer necessary to further correct its work [3, 14, 15].

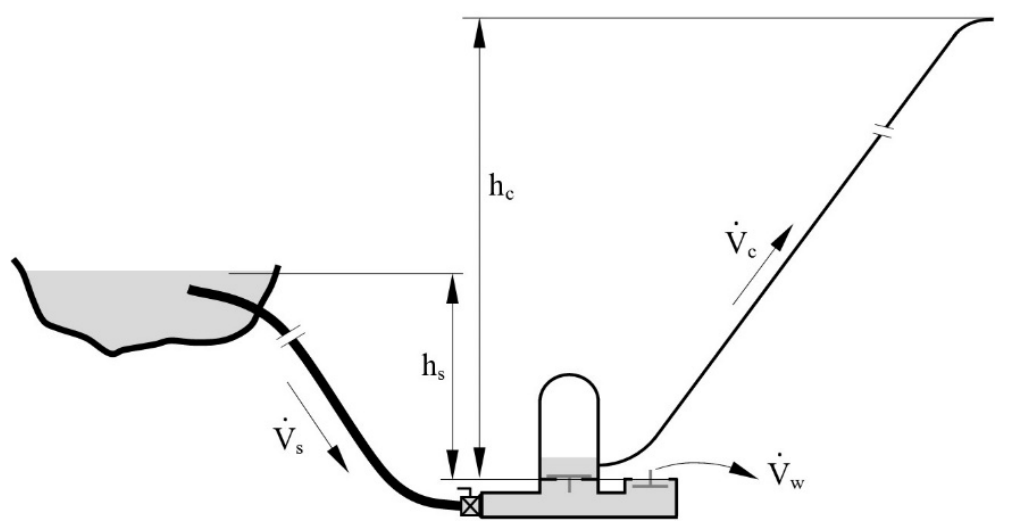

Fig. 1. Scheme of water ram (source: own materials)

Rys. 1. Schemat tarana wodnego (źródło: materiały własne)

Analyzing history of the water ram can find information describing how the rams were testing $[1,9,10]$. Already in 1804 Eitelvein (in Germany) performed more than 1000 experimental trials for their actions $[12,15]$. In subsequent years appeared first publications among others in magazines such as The Farmer's 
Cabinet and The American Farmers in United States [3, 5, 11] where were also contained information concerning their performance. In 1834 American entrepreneur Strawbirge $\mathrm{H}$. began mass production of this type devices (but not managed to find literature information how the devices were tested and how determined the parameters their work).

James Clarke (designers of water rams) [3] in his book gives information about the water ram and various types the measures test stands. Clarke [3] gives the results of measurements carried out on the basis tests in which were made changes in individual elements of the test stand for example: water tanks, pipe lengths, bends, etc.

John Calhoun [2] in his publication show the whole process of building a water ram and their individual components also he published commentary, how to prepare various elements of water ram, described the principle of operation, gives performance results and the simple mathematical equations.

Manufacturer of the water ram Derkor [4] (China) on his website gives a lot of information on produced water ram inter alia technical specifications, performances. Derkor [4] presents various diagrams of measuring test along with their regulatory capabilities of water ram.

Another example is a company manufacturing ram pump in Thailand, Meribah Ram Pump [13] performed tests under natural conditions and on a professional test stand.

In depending where the test stand of water ram is placed can be made their division:

1. Professional test position - these are special placed having regulations of level of supply source and delivery water. This group includes mainly manufacture of water ram.

2. Natural place - the source of the water is a lake, stream, river, etc., while place of water delivery is tank located higher than the water source for example water tower. An example of such an installation is the water ram in village Kajny close Olsztyn (Poland) (Fig. 2). It should be noted that the regulate of the height source water is carried out by placing the drive pipe in appropriate place of the stream while regulate of the height level of the delivery water by placing outflow in appropriate height level of hills (by manipulated the piping length are obtained appropriate levels of the supply source and water lifting).

3. Temporary placed (unprofessional test stand) - usually are places in the household where the position was built with makeshift elements (pallets, ladders, platforms, etc.). Such test stands are to check in the context of their actions (whether this ram at all working). The water sources are usually tanks once filled water and the height of delivery is checked using racks for example: ladder, pole, boom, tree, part of buildings, etc. 

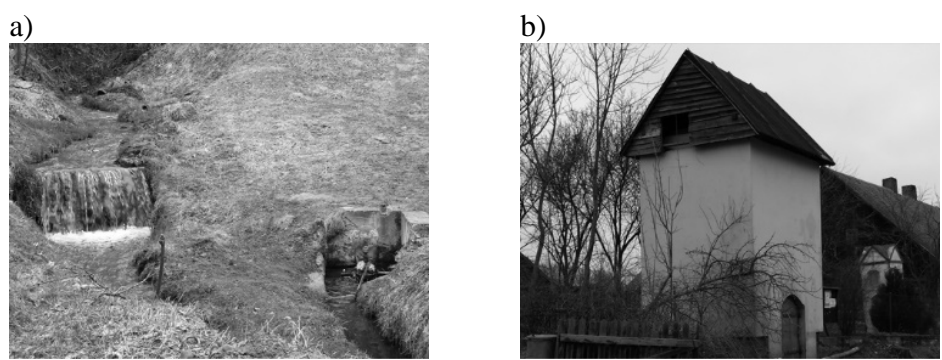

Fig. 2. Water ram in village Kajny: a) water ram and stream, b) water tower (source: own materials)

Rys. 2. Taran wodny we wsi Kajny: a) taran wodny i strumień, b) wieża ciśnień (źródło: materiały własne)

\section{The construction recommendation}

The work on the construction of test stand began to draw up a list of requirements. Requirements for the test stand were developed based on previously performed test stands on which were made a series of tests. The test stand should comply with the following assumptions.

- functionality - the construction should be adapted to the possibility of carrying out various studies, modernization, expansion, dismantling, transport the whole structure or its part.

- cheapness - the structure should be made of components generally available in retail chains but with an appropriate quality components or assemblies of the test stands.

- reliability - construction should allow for testing without failure for not less than projected include the nature and conditions of work of ram water.

- durability - construction should maintain the stability of the entire system take into account the conditions of the study.

- lightness - the structural (their elements and measuring system) should be constructed from materials to allow expansion whole test in easy way, transportation for example in natural conditions.

- faithfulness to natural conditions - the structure should largely replicate natural conditions.

- easy of operation - design should ensure operation easy access to the adjustment points, ease of maintenance and repair, disassembly, replacement of components.

- environmental protection - protection of the environmental and the working environmental in accordance with applicable regulations and standards. Compliance with the requirements of construction safety and health.

On the basis of these construction recommendations made proposals for built of the test stands. 


\section{The supply system}

The supply system of water ram in the natural conditions is any flowing watercourse for example river, stream, etc. It is important that such a flowing watercourse must provide adequate velocity flow of water to the water ram. The water ram to its work uses the kinetic energy of flowing water. Quickly stop the flow of water by closing the impulse valve creates the water hammer in working zone. The water hammer effect on its the correct operation and its performance. In the laboratory these natural source of water should be replaced with an element that could accumulate a certain amount of water. It is this purpose can use: tubes, trays, tanks, cylinder, etc., but keep in mind to ensure a constant supply of water.

Proposals supply source of water ram is shown in Figure 3. The system shown in Figure 3 a was created with supply source water where uses a water tank (1) with supporting system and electro-mechanical system (2). To the built construction were used scaffolding (20 frames) with its subsequent possibility reconstruction or expansion. The scaffolding was set in a wood level bench (3). In the center of scaffolding (4) was inserted water tank (1) suspended by steel slings (5) to the hook (6) electro-mechanical winch (2) with a capacity of $1000[\mathrm{~kg}]$. The electro-mechanical winch mounted to a structural bench (7). Lifting the tank is via the control panel (8). In this way performed the construction allows for smooth adjustment of the water supply source to the specified height using the electric winch (lifting or lowering the tank). The height reading occurs by using a tape measure (9) or a pressure gauge (10). The used way to suspension of tank allows to change its quickly.

Alternatively, to this proposal is to use water cylinder of sufficient width (1) and height show in Figure 3b. The water supply source positioned vertically on a level construction bench (2). In the lower part of the cylinder mounted flow out of water (3) that is connected to the water ram and connectors to the city water (4). The regulation height of level water is the basis on maintenance of the appropriate amount of the water in the cylinder (system). The height of water level is reading by use a measuring tape (5) end a pressure gauge (6).

\section{The receiving system}

The receiving system of water ram (delivery point / collector) (Fig. 4) is used to receive water that was lifted (pumped) by water ram. In natural conditions this is usually a water reservoir (tank) located at a height substantially higher than the water source for example water tower.

The proposal of the receiving system shown in Figure 4. To build this system uses flexible pipe (1) that water flow from the water ram to the collector (3). The pipe is connected by means of the quick couplings with steel pipe (2) that is a sling for this system. The pumped water by pipe (1) and the steel pipe (2) flow 
to the tank (3) (collector) that was made from steel pipe with diameter 2 [in] (the collector capacity $1.5\left[\mathrm{dm}^{3}\right]$ ). The use of such collector provides the ability to collect time there a lite among of water for example at the malfunctioning of the ram, delivery part or all system. Next the water flows freely by pipe (4) to the measurement system shown in Figure 5 or 6 . Adjusting of the height of the system is done using rope (5) mounted to winch. Reading height is carried out using a tape or an electronic rangefinder.

a)

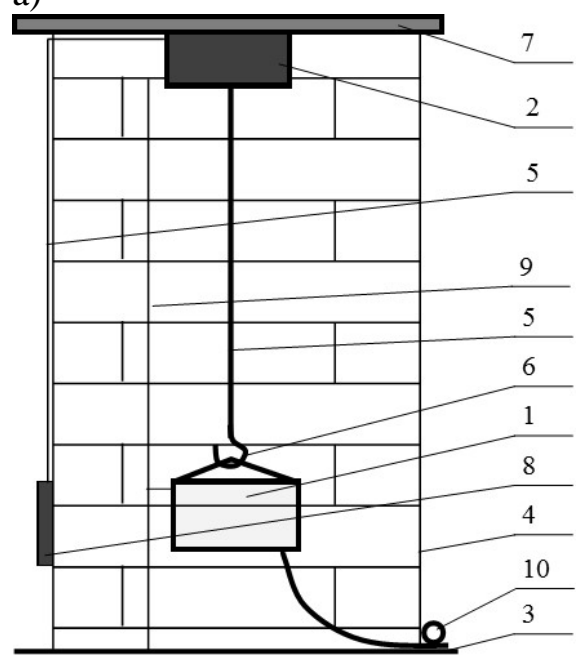

b)

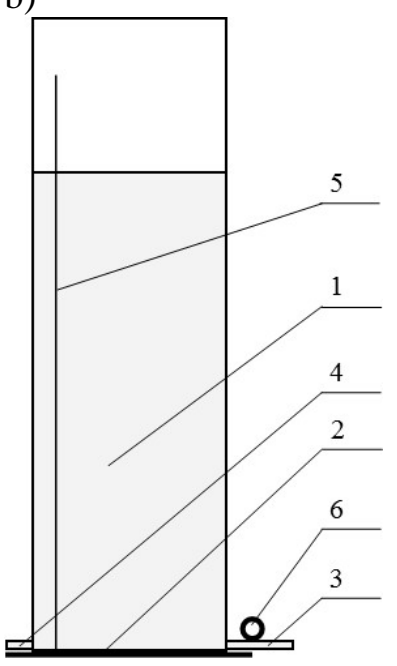

Fig. 3. The supply system: a) water tank, b) water cylinder (source: own materials)

Rys. 3. System zasilający: a) zbiornik wodny, b) cylinder wodny (źródło: materiały własne)

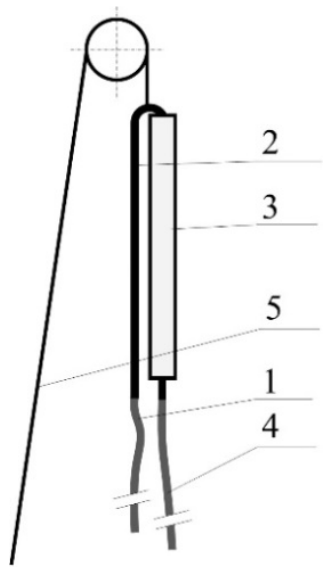

Fig. 4. The receiving system (source: own materials)

Rys. 4. System odbiorczy (źródło: materiały własne) 


\section{The measurement system}

The performance of water ram can determine uses the mass or volumetric flow rate. Presented below proposal such systems allows to measure flow rate in two zones at the same time. The mass flow rate system is shown in Figure 5. It consists with two intermediate tanks (1 and 2) that are suspended on the force sensor (3 and 4) and main tank (5). The tank (1) receives water with working zone of the water ram that flow by impulse valve and the tank (2) receives water with pressure zone (from collector). To the tanks (1 and 2) mounted stop valves (6 and 7). The main tank (5) is equipped with a pump (8) and elastic pipe (9) leading to the tank ( 1 in Figure 3 ) constituting the supply water source of ram. These elements allow operation of test stand without a continuous supply water from outside, trebly significantly reducing the cost of testing.

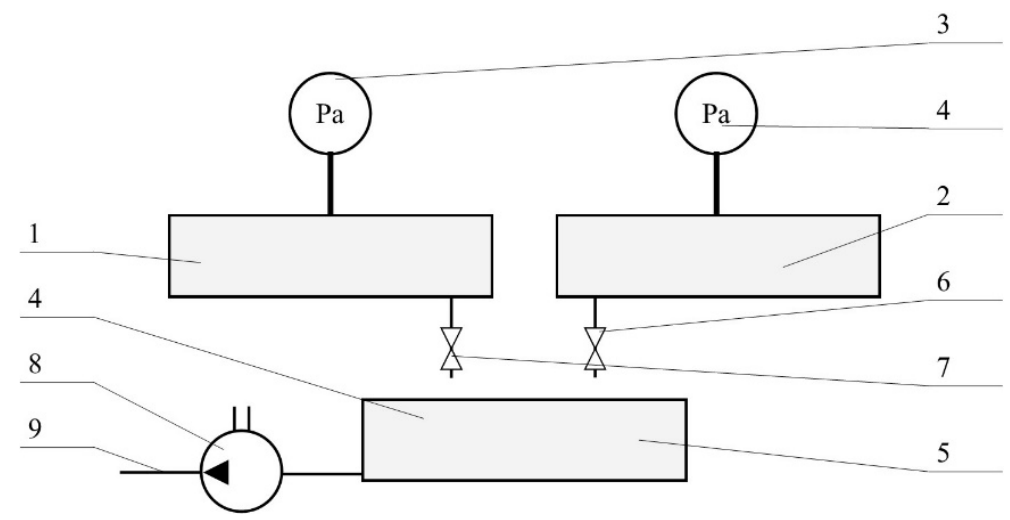

Fig. 5. The mass rate flow system (source: own materials)

Rys. 5. System pomiarowy masowego natężenia przepływu (źródło: materiały własne)

The volumetric rate flow system is presented in Figure 6. It consists of two intermediate tanks ( 1 and 2 ) where below mounted water meter (4 and 5) equipped with pulsars $\left(1\right.$ pulse $\left.-1 \mathrm{dm}^{3}\right)$. The water meters were connected to an electronic counters pulses (6 and 7). Directly from the counters pulses takes readings of the amount of water that flow appropriate zones. Next the water flows into the tank (3) and form there via the electric water pump (8) and elastic pipe (9) to the main supply tank.

The choice of method is made on the basic of the testing time and its accuracy. The method of measuring mass flow rate allows for quick execution of the study. The mass of water gathering in tank can be read directly from the sensor. Long term study (week, month) is performed using volumetric flow rate. The choice of method volumetric flow rate can additionally check the all terms of the constructions recommendations. 


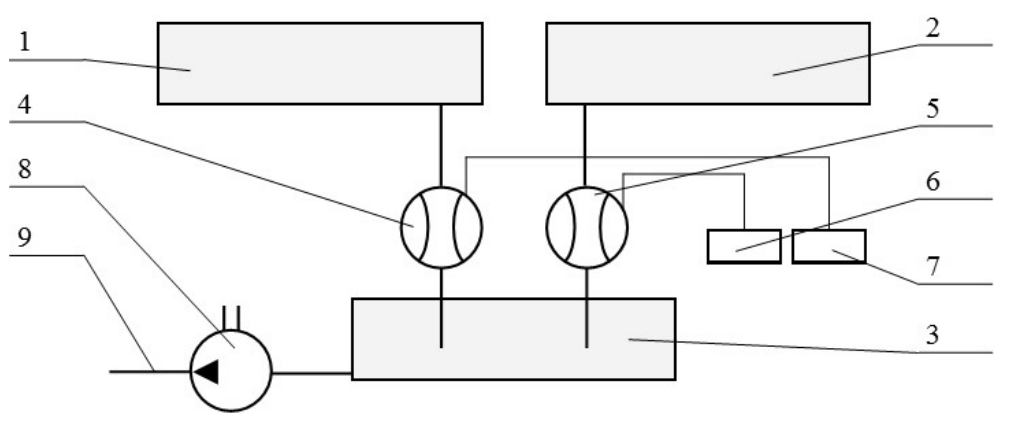

Fig. 6. The volumetric rate flow system (source: own materials)

Rys. 6. System pomiarowy objętościowego natężenia przepływu (źródło: materiały własne)

\section{The test stand}

In Figure 7 presented in whole proposal of the test stand to measure a variety physics phenomena occurring in water ram during its operation taking into account the constructions recommendations. The biggest trump of this test stand is the ability to adjust the height of supply water source and lifting water in smooth way.

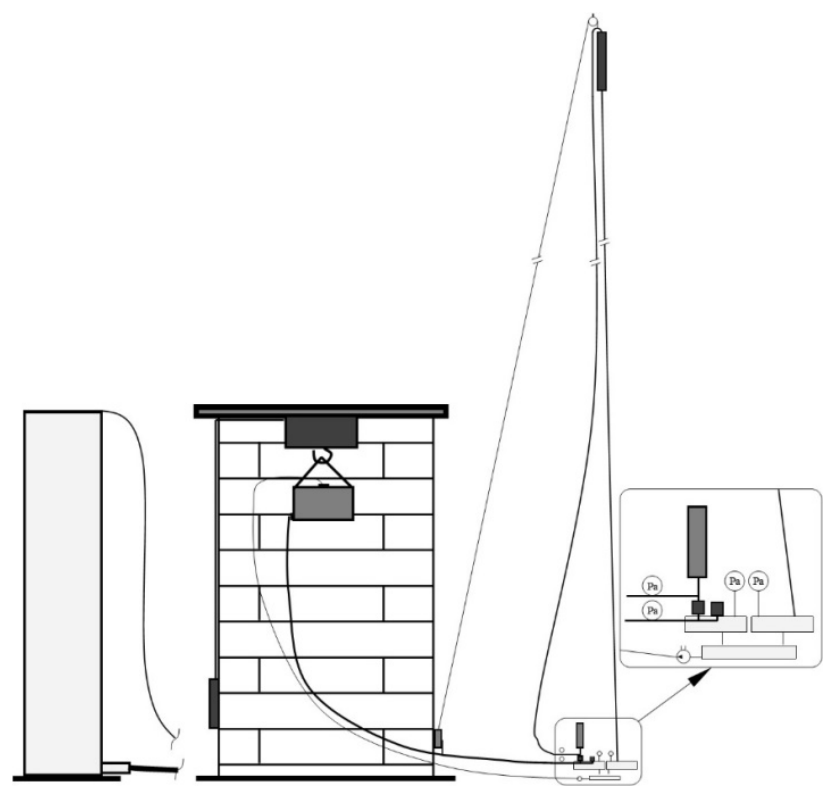

Fig. 7. The test stands to measure phenomena accruing in ram water (source: own materials)

Rys. 7. Stanowisko testowe do badań zjawisk zachodzących w taranie wodnym (źródło: materiały własne) 


\section{Conclusions}

The main aim of this article was proposal for built the test stand used to the measure various studies occurring while working in water ram based on the construction recommendations.

Shown the test stand meets all requirements in terms of construction recommendations. The main advantages of this whole system is its functionality. To the advantages may also include a quick replacement of individual components as necessary (pipes, structural elements, etc.) and the entire system or its part can be transported to another location. The test stand can be easily expanded to the current needed of research for example public shown of water ram action (popularization of water ram) (Fig. 8). The proposed measurement system mass and volumetric flow rate ensure easy testing. I should also mention environmental protection. The present process flow water will not be wasting the water even over long periods of testing. The stable and durable components ensure the safety perform the study.

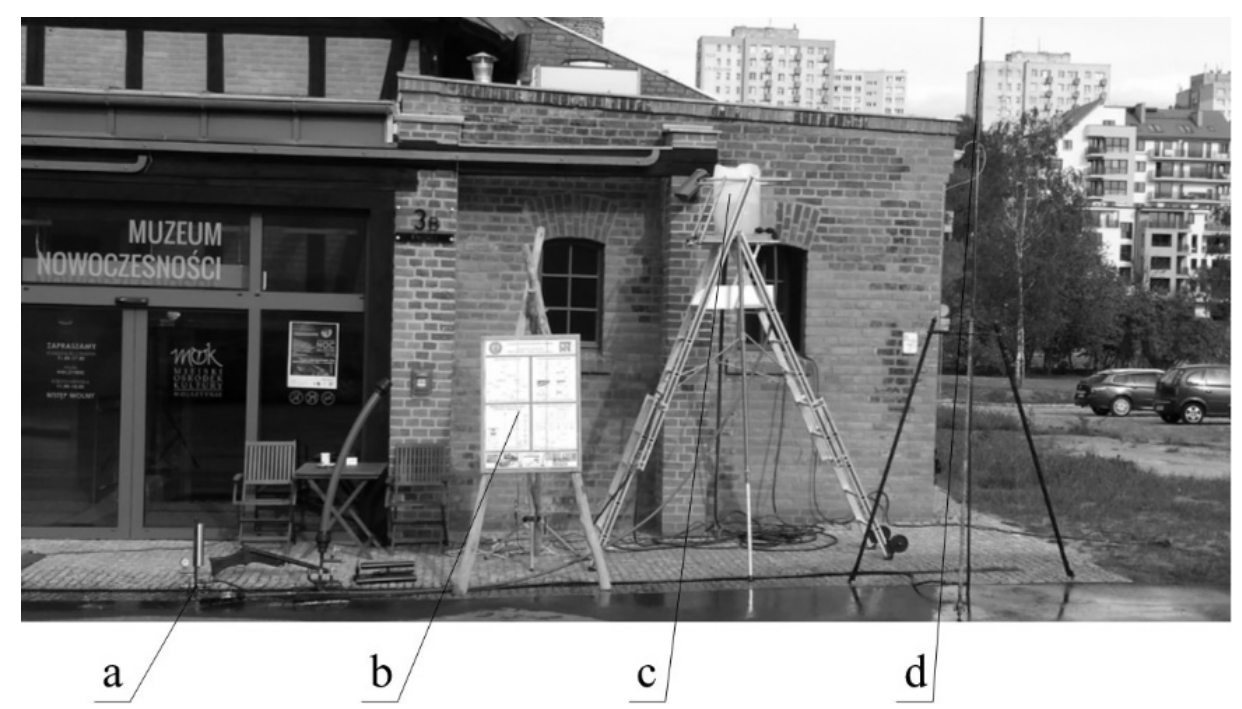

Fig. 8. Public shown of water ram action (Museum of Modernity in Olsztyn): a. water ram, b. information board, c. supply water source, d. water delivery (source: own materials)

Rys. 8. Publiczny pokaz pracy tarana wodnego (Muzeum Nowoczesności w Olsztynie): a. taran wodny, b. poster, c. system zasilający, d. system dostarczania wody (źródło: materiały własne)

\section{References}

[1] Awulachew S.: Pumps for small-scale irrigation, 2009, Retrieved from http://ilri.org/infoserv/Webpub/fulldocs/IWMI_IPMSmodules/Module_4.pdf. 
[2] Calhoun J.: Home built hydraulic ram pumps, 2003, Retrieved August 2014, from http://www.homepower.com/how-ram-pump-works.

[3] Clarke J. W.: Hydraulic rams their principle and construction, 1900, Retrieved from https://archive.org/details/hydraulicramsth03clargoog.

[4] Derkor: How does hydraulic ram work? 2014, Retrieved from http://www.rampumps.net/face/20120410150106.html, March 2014.

[5] Furze J.: Compendium in hydraulic ram, University of Aarhus. Faculty of Political Science, 2012, Retrieved from http://www.slideshare.net/Fatin62c/compendium-inhydraulic-rampumps.

[6] Grygo D.: Ram pump - the forgotten device (in Polish), 2014, Poznan: III National Conference of Students Scientific Research, ss. 68-80.

[7] Grygo D., Sobieski W.: Proposals for the use of water rams (in Polish), 2015, Retrieved from http://www.itep.edu.pl/wydawnictwo/woda/index.php?id=zeszyt _50_2015\&rr=1.

[8] Grygo D., Sobieski W., and Lipiński S.: Stages work of water ram (in Polish), 2014, Retrieved from http://www.oficyna.portal.prz.edu.pl/pl/zeszyty-naukowe/ czasopismo-inzynierii-ladowej-s/jceea-61/jceea-613-1-14.

[9] Jennings G.: Hydraulic Ram Pumps. Waret Quality \& Waste management, 1996, pp. 4-6.

[10] Jong P.: Hydraulik rams. Delf University of Technology, 2015, ss. 4-6.

[11] Lansford W. M., Dugan W. G.: An analytical and experimental study of the hydraulic ram, Bulletin of the University of Illinois (United States), Vol. XXXVIII, No. 22, 1941.

[12] Maruchin W., and Kutienkow W.: A hydraulic ram - thoroughly forgotten the old idea (in Polish), 2014, Retrieved from http://www.pinopa.republika.pl/ Tarpend_pl.html.

[13] Meribah Ram Pump: Meribah Ram Pump Proved \& reliable Water Pumping Solution. Retrieved from http://www.meribah-ram-pump.com/index.php?id=29, 2014.

[14] Mohammed S. N.: Design and Construction of a Hydraulic Ram Pump. Leonardo Electronic Journal of Practices and Technologies, Vol. 11, 2007, pp. 59-70.

[15] Watt S. B.: A manual on the hydraulic ram for pumping water, 1975, Retrieved from http://www.watersanitationhygiene.org/References/EH_KEY_REFERENCES /WATER/Water\%20Pumping/Ram\%20Pumps/Hydraulic\%20Ram\%20Pump $\% 20$ Manual\%20(ITDG).pdf.

\section{PROPOZYCJA BUDOWY STANOWISKA POMIAROWEGO DO BADAŃ RÓŻNYCH ZJAWISK ZACHODZĄCYCH W TARANIE WODNYM W OPARCIU O ZALECENIA KONSTRUKCYJNE}

\section{Streszczenie}

Głównym celem artykułu było opracowanie stanowiska laboratoryjnego służącego do przeprowadzania badań zjawisk zachodzących podczas pracy w taranie wodnym w oparciu o zalecenia konstrukcyjne. Zalecenia konstrukcyjne opracowano na podstawie wcześniej wykonanych oraz testowanych prowizorycznych stanowiskach pomiarowych. Zdobyte doświadczenie na podstawie 
wielu prób pozwoliło na opracowanie zaleceń konstrukcyjnych stanowiska, które umożliwiają dostosowanie stanowiska do wykonania różnych badań zjawisk występujących podczas pracy tarana oraz łatwe dostosowanie stanowiska do nowych potrzeb. Artykuł zawiera: przegląd stanowisk pomiarowych na których dokonywano pomiarów w przeszłości oraz współczesnych, zalecenia konstrukcyjne do budowy uniwersalnego stanowiska pomiarowego oraz propozycję budowy stanowiska pomiarowego opartego o zalecenia konstrukcyjne. Motywacja do zajęcia się tą tematyką wynikła z zainteresowań urządzeniami, które pracują w sposób niekonwencjonalny wykorzystujące energię odnawialną, do których niewątpliwie należą tarany wodne, urządzenia, które można wykorzystać w gospodarstwach domowych. Analiza literatury na temat taranów wodnych oraz ich wydajności wykazała, iż jest ona niewielka i są to zazwyczaj stare opracowania $\mathrm{w}$ formie popularno-naukowej. W czasach intensywnych poszukiwań nowych źródeł energii odnawialnej reaktywacja tego typu urządzeń może okazać się wysoce prawdopodobna.

Słowa kluczowe: taran wodny, stanowisko laboratoryjne, uderzenie hydrauliczne, wydajność

DOI: $10.7862 / \mathrm{rb} .2016 .155$

Przestano do redakcji: 01.05.2016 $r$.

Przyjęto do druku: 28.06.2016 r. 